\title{
Zaynab Alkali'nin The Stillborn Eserindeki Nijeryalı Alt Sınıf Kadının Durumunun Yapıbozucu Açıdan Okunması
}

\section{Dr. Öğretim Üyesi Yakut Akbay ${ }^{1 *}$}

Gelis tarihi: 29.05 .2020

Kabul tarihi: 17.06 .2020

\section{Atıf bilgisi:}

IBAD Sosyal Bilimler Dergisi

Sayı: $8 \quad$ Sayfa: $308-318$

Yıl: 2020 Dönem: Güz

This article was checked by iThenticate. Similarity Index 17\%

Bu makalede araştırma ve yayın etiğine uyulmuştur.

\footnotetext{
1 Ankara Bilim Üniversitesi, Türkive, yakutakbay@gmail.com,

ORCID ID 0000-0003-1557-232X
}

\footnotetext{
* Sorumlu yazar
}

\begin{abstract}
ÖZ
Günümüzde Afrikalı kadınlar yurtiçinde ve yurtdışında ulusal edebiyatın geliştirilmesinde aktif rol almaktadır. Fakat kadın yazarların edebiyat sahnesinde yer almaları hemen gerçekleşmemiştir. Sömürgecilikten sonra Afrika'da edebiyat alanı erkek egemen olmuștur. Bu nedenle, Afrikalı kadın tanımı ataerkil toplumun normları tarafından belirlenmiş yanlış betimlemeler üzerine kurulmuştur. Kadın edebiyatının ortaya çıkması, erkek yazarlar tarafından oluşturulmuş kadınlık tanımlamalarına direnmek ve yeniden yapılandırmak için kaçınılmaz bir gelişme olmuştur. Bu çalışmanın amacı, Spivak'ın alt sınıf kadın kavramını Nijerya kültürü kapsamında Zaynab Alkali'nin The Stillborn (1984) eseri temelinde inceleyerek yabancılaştırmaktır. Çalışmada, Spivak'ın alt sınıf kadın tanımının aksine, Nijeryalı alt sınıf kadının erkek egemen toplumda sesini duyurabildiği iddia edilmektedir. Afrika feminizmi, Nijerya kültüründe kadınlığa atfedilen anlamları irdelemek için yerel bir eleştiri olarak uygulanmaktadır. Derrida'nın yapıbozucu kuramı, metin ve metnin anlamı arasındaki tutarsılık ve uyuşmazlıkları ortaya çıkarmak amacıyla yapılan bu araştırmanın teorik çerçevesini oluşturmaktadır. Araştırma, Derrida tarafindan tasarlanan ikili, logocentrism, différance ve aporia gibi bir dizi terim ve kavramları içermektedir.
\end{abstract}

Anahtar Kelimeler: Afrika Feminizmi, Alkali, Kültür, Différance, Alt Sınıf. 


\title{
A Deconstructive Reading of the Nigerian Subaltern in Zaynab Alkali's The Stillborn
}

\author{
Assist. Prof. Dr. Yakut Akbay ${ }^{1 *}$
}

First received:29.05.2020

Accepted: 17.06 .2020

\section{Citation:}

IBAD Journal of Social Sciences

Issue: $8 \quad$ Pages: $308-318$

Year: $2020 \quad$ Session: Fall

This article was checked by iThenticate. Similarity Index $17 \%$

1 Ankara Bilim University, Turkey, yakutakbay@gmail.com, ORCID ID 0000-0003-1557-232X

\begin{abstract}
Nowadays African women are taking an active role in the development of national literature both at home and abroad. However, the advent of female writers to literary arena was not a sudden event. After decolonisation, African literary sphere was heavily male dominated. Hence, the portrayal of the African woman was based upon the misrepresented image predetermined by the norms of patriarchal society. The emergence of women's writing in Africa was inescapable and necessary to resist and reconstruct meanings of womanhood created by male writers. The purpose of the present paper is to defamiliarize Spivak's subaltern as a female subject within the context of the Nigerian culture in Zaynab Alkali's The Stillborn (1984). It is argued that as opposed to Spivak's subaltern, the Nigerian subaltern can speak up for herself in the male-dominated society. African feminism is applied as a vernacular criticism to scrutinize meanings attributed to womanhood in the Nigerian culture. Derrida's deconstruction constitutes the theoretical framework of the study to reveal inconsistencies and controversies between the text and its signification. To this end, the research involves a number of terms and concepts devised by Derrida such as binary, logocentrism, différance and aporia.
\end{abstract}

Keywords: African Feminism, Alkali, Culture, Différance, Subaltern.

\section{* Corresponding Author}




\section{INTRODUCTION}

African women play a significant role in the development of education and literature. Their initial art was verbal and didactic making a notable contribution to oral literature shaping African cultures and nations. These traditional values are instilled in young generations through prayers, lullabies, proverbs, riddles, and folksongs. The oral heritage transmitted by women also paved the way for the emergence of African fiction. However, because of social and economic reasons, women were not able to transfer this to the art of writing, which is why most of the literature produced after decolonization was heavily male dominated. According to Busby (1996), what is regarded as African Literature, usually written in European languages, has a recent history dating from the 1950s with the publication of works such as Chinua Achebe's Things Fall Apart (p. xiii). Busby expresses her pessimistic approach concerning the absence of women from most early anthologies of African writing. She explains this situation on the grounds of gender roles ascribed to them by the male-dominated society. Busby states that while male writers initially focused on the theme of colonization by Western powers, women, in addition, had to struggle against colonization by their own men and the traditional norms by which formal education was reserved exclusively for men (p. xiii). Indeed, most women writers believe that their voice in literature is subsumed under the repressive influence of their male counterparts, who have been brought up to take women for granted. Adeola James (1997) argues that, "our problem is that we have listened so rarely to women's voices, the noises of men having drowned us out in every sphere of life, including the arts. Yet women too are artists, and are endowed with a special sensitivity and compassion, necessary to creativity" (p. 6). For this reason, women writers promote the idea of equality in literary sphere where male writers must change their prejudiced view on their disdainful and grudging acknowledgment of women's writing.

It is noteworthy that the present-day African women's writing owes a great deal to the legacy of firstgeneration women writers. In this regard, Zaynab Alkali is considered one of the pioneers of women's writing from Africa and the first woman writer from Northern Nigeria. The Nigerian novelist Zaynab Alkali received a doctorate degree in African literature (Whitsitt, 2012, p. 178). After twenty-two years of university work, she took a three-year break and worked for the National Primary Health Care Development Agency in Abuja (p. 178). In 2009, she was appointed as dean of the Faculty of Arts at Nasarawa State University, where she teaches creative writing and African literature in English. In her novels, Alkali addresses the issues concerning the condition of women in patriarchal African cultures. The author usually sets her stories in rural areas of Northern Nigeria to explore how communities come to terms with rapid social changes taking place in their daily lives. She also expresses a strong belief in the necessity of female education, which is accentuated in most of her novels and short stories. Alkali's debut novel The Stillborn, published by Longman in 1984, was hailed as the "lone female voice from the north" of Nigeria (Ugbabe, 1998, p. 15). In The Stillborn, Alkali is concerned with the life of the Hausa people constituting one of the largest ethnic groups in West Africa.

Nigeria has a large and diverse population consisting of more than 200 different ethnicities (Falola \& M. Heaton, 2008, p. 4). However, the main ethnic groups that make up the majority of the population are the Hausa, the Yoruba and the Igbo people. The Hausa people live in the northern part of Nigeria and constitute roughly 21 percent of the population, whereas the Yoruba people, who live in the southwestern part of the country, make up 20 percent, and respectively, the Igbo people live in the southeast area accounting for nearly 17 percent (p. 4). These multiple ethnic groups shape the culture of Nigeria. Apart from diverse population, there are two major religions in Nigeria, Christianity, and Islam, both of which are practiced by nearly half of the population of the country (Phillips, 2004, p. 57). Christianity prevails in the southern part of the country, while Islam in the north (p. 57). Some Yoruba and almost all the Hausa and Fulani people are Muslim (p. 57). Culturally, Nigerian people are influenced both by their local traditions and values and lifestyles adopted from the West (Falola \& M. Heaton, 2008, p. 6). In addition to this, polygamy is still commonly practiced in the country, while monogamous marriage is prevalent among Christians and the educated elite (p. 6).

Since both Indian and Nigerian societies are patriarchal in nature, this makes it possible to adopt Spivak's subaltern for the study of the Nigerian cultural context. In her essay "Can the Subaltern Speak?", Spivak views subaltern as a female subject. She argues that the question of 'woman' seems 
more problematic because "if you are poor, black and female, you get it in three ways" (1987, p. 294). She develops a gendered analysis of the subaltern by examining the situation of Indian women and their representation in Western discourses. Spivak states that the subaltern is unable to raise her voice since "there is no space from which the sexed subaltern subject can speak" (p. 307). Therefore, she is (mis)represented by the discourse of the male-dominated West and the male-dominated East. The author concludes her essay by reiterating her pessimistic standpoint that "the subaltern cannot speak" (p. 308). The aim of the present research is to defamiliarize Spivak's pessimistic approach concerning the condition of the female subaltern in terms of the Nigerian woman, who, even living in a patriarchal society, carves out her own space from where she can speak up for herself. In this regard, the deconstructive reading of the text in the light of African feminism serves as backing to the above argument of the study.

In The Stillborn (1984), Alkali treats the themes of contemporary Nigeria from the authentic perspective of a woman raised in traditional norms and values of the male-dominated society. The novel is rich in dialogues, flashbacks and dreams exposing or foreshadowing particular events in the novel. The protagonist $\mathrm{Li}$, a thirteen-year-old girl, returns home after completing her primary education. Being restless and impulsive by nature, she finds the atmosphere in her father's compound suffocating (The Stillborn, 1984, p. 3). The household regards Li's independent spirit as impatience and stubbornness (p. 4). She is expected to perform the usual household chores as every young girl does - sweeping the compound, fetching water from the stream and firewood from the neighbouring area and washing dishes. However, "she was dreaming of a paradise called the 'city'. A place where she would have an easy life, free from slimy calabashes and evil-smelling goats. She looked down at her coarse hands and feet. One of these days she would be a different woman, with painted nails and silky shining hair" (p. 55). Later, she meets Habu Adams, a young man from the village whom she plans to marry and settle in the city. They would live in a big European house full of servants. However, after they marry, when she is fifteen, Habu abandons her in the village. Four years pass. Finally, she goes to the city to find her husband. She discovers that he has failed to become a doctor and earns his living as a salesperson. Moreover, he has taken another wife. The city holds nothing for $\mathrm{Li}$ except frustration and despair. The spontaneous and spirited girl becomes a grim and sober-minded woman. "It destroys dreams," she says of the city (p. 94). One day Li dreams that her father's home has burned down; she hurries back to the village and finds that he has died of an illness. She is pregnant and gives birth to a daughter, Shuwa. Eventually, she becomes 'the man of the house' (p. 101) a position for which she has been psychologically preparing herself. Li knows that she has to find her own happiness, and by the end of the novel, at twenty-nine, she completes her studies at the Teachers' College and becomes a successful teacher.

The role of education in the awakening of self-awareness of the main character is one of the recurrent themes in the novel. This is suggested from the very beginning of the novel when the protagonist $\mathrm{Li}$, being a thirteen-year old girl, is returning to her village after finishing her primary education, which is considered the only education appropriate for girls in the Hausa community. In fact, the restricted access to education is one of the serious issues in Nigeria affecting women's position in society. This gender inequality stems from patriarchal cultural norms which relegate women primarily to the domestic sphere. In the Hausa system, girls are mainly involved in domestic labour as well as the care of younger siblings, whereas boys are spared for education in the hope of subsequent access to waged labour or higher education (Pittin, 2002, p. 351). For girls, education is regarded as a "temporary diversion before entering into marriage, childbearing and home- and farm-based subsistence production" (p. 351). Thus, girls are denied the right to proceed further, that is, to higher schooling. Alkali, as an advocate of social reform, underscores the importance of female education throughout the novel. She strongly believes in self-fulfilment of Nigerian women attained through education since literate women help to educate the children, which is aptly reflected in the Nigerian catchphrase "educate women and you educate a nation" (p. 340).

The sad feelings of Li's homecoming are accompanied by an elaborate description of the village. It is depicted as "large and unequally cleft in two by a long narrow stream, almost hidden by its bushy banks" (The Stillborn, 1984, p. 2). The smaller side of the village is less crowded thus appears to be quiet and deserted consisting of "farmland and a few scattered mud huts" (p. 2). However, on the 
opposite and larger side, "flourished a long stretch of fruit trees, richly dressed in green" (p. 2). Since the larger part of the village is more populated, it "lay sprawled in clusters of thatched mud huts" ( $p$. 2). The use of such words as 'flourished' and 'green' stands for liveliness and development of the village. On the other hand, peace, and quiet dominating the smaller part of the village, suggest the innocent and natural state of the idyllic rural life cherished by the villagers for centuries. However, the image of village ends with a range of hills, at the base of which there are the European quarters known as the Hill Station (p. 2). The houses in complete contrast to those in the village are "built of stones and roofed with asbestos" (p. 2). The gigantic view of modern houses evokes an uncanny feeling, which the author develops by providing a further description: "Built on a much higher plane and facing the rest of the village, they [the houses] had assumed the look of an overlord. This advantageous position was further heightened by a thick overgrowth of trees that shrouded the houses, giving them the desired privacy" (p. 2). The description of the village reveals the binary opposition between modernisation gradually permeating the rural life and tradition. It is implied that modernisation is gaining ground by becoming an authority in the rural domain. Even the generator in the village "lent its light only to the Hill Station and the Memorial Hospital" and "a visitor at night was apt to think that only these two places existed in the village" (p. 2). The sound of the generator is contrasted with the rustic voices of the villagers. By going to sleep and getting up by the sound of the electricity generator, the villagers are slowly being adjusted to the way of life introduced by modernisation. The process of usurpation taking place in the rural area may be regarded as a "dangerous supplement" to tradition since it is replacing the norms of the rural community, whose rituals and traditions have been cherished for many centuries being handed down through many generations (Of Grammatology, 1997, p. 149).

Li's father, Baba, is the patriarch of the family madly obsessed with discipline. His household principles make Li feel "trapped", "suffocated" and "unhappy" (The Stillborn,1984, p. 3). She abhors the 'don'ts' that have heavily outnumbered the 'do's' (p. 3). Her rebellious nature does not allow her to blindly accept and obey these rules. She considers them stupid and unnecessarily rigid (p. 3). The signifiers 'suffocating' 'trapped', 'unhappy' 'restrictions' and 'prison' connote patriarchal oppression consigning women to the subaltern position. With so many restrictions imposed by her father, $\mathrm{Li}$ assumes that the only way to escape from this 'prison' is to marry Habu and move to the city. Her daydreams of the city, which she calls 'paradise', start to take shape after she meets Habu (p. 55). They are also embellished by exaggerated images of "a big European house full of houseboys and maids" (p. 55). Li virtually loses touch with reality when she dreams of "the luxuries the city could offer" (p. 57). She is unaware that "her feet barely [touch] the ground" (p. 55). Being completely unfamiliar with urban life, Li creates her own myth of the city full of wonderful and exciting things where young people are "eager and ready to enjoy life to the fullest" (p. 57). In fact, the young people who are tired of the norms and restrictions of their community regard the city as the place where they can live freely without any obligations. Besides, the city, standing for modern values, offers new opportunities for them. However, the villagers belonging to the older generation are opinionated about urban life and modern values. They believe that the "dangerous supplement" called modernisation is encroaching on rural way of life gradually destroying its tradition (Of Grammatology, 1997, p. 149). In the Derridean sense, this way of life is a "garment of perversion and debauchery" and "a dress of corruption"; therefore, these elements of modernisation become "seductive" leading "desire away from the good path" (pp. 35,151). Similarly, the main concern of the rural community is that modernisation will eventually usurp traditional values entailing degeneration. However, they refuse to admit the fact that "usurpation has already begun" (p. 37).

Apart from the dichotomous relationship between modernisation and tradition, The Stillborn addresses the condition of the Nigerian woman in terms of local customs and various aspects of womanhood, which makes it possible to examine the Nigerian subaltern within the vernacular female discourse known as African feminism, otherwise called African womanism. African feminists are different from their western counterparts in that "by using the term 'woman' as a universal group", the former are "only defined by their gender and not by social classes and ethnic identities", whereas Western feminists "ignored the voices of non-white, non-western women for many years" (Bayu, 2019, p. 55). Moreover, "Third World feminism considers gender discrimination neither the sole nor perhaps the 
primary focus of the oppression of Third World women" (p. 55). According to Mary Kolawole (1997), African womanism "embodies a set of values that reconstructs a more accurate, a more valid and a more authentic wholesome African feminine consciousness and actions" (p. 204). She expands this concept further, "African womanism cannot be separated from humanism. Rather, it seeks to enrich the female gender through consciousness-raising while giving a human touch to the struggle for the appreciation, emancipation, elevation and total self-fulfilment of the woman, in positive ways" (p. 204).

African womanism is an accommodating and valid criticism to analyse such issues as bride price, polygamy, male child preference and infertility depicted in The Stillborn. To begin with, the novel suggests that as a custom, bride price is still practiced in most rural parts of Nigeria. Bride price is part of tradition according to which a bridegroom is supposed to give a sum of money or other valuables to the family of the bride. However, most young bachelors in rural areas do not welcome this tradition because they find it difficult to accumulate enough savings to pay the bride price. Garba, one of the male characters in The Stillborn, aptly remarks that "getting married is not expensive in the city" and that "a man can live with a woman of her own free will without having to pay anything" (The Stillborn, 1984, pp. 44-5). Alluding to the issue of bride price, Buchi Emecheta recounts her own situation when she was young and literally put up for sale. She states that she comes from a place where a woman is paid for (Emecheta as cited in Ngcobo, 1988, p. 151). She resentfully remembers that while her family could not afford to pay for her education, which she accomplished with the help of scholarships, they readily bargained for her as people do in the bazaar when it came to the bride price (p. 151). Moreover, by proudly declaring that she has English education, they pushed up her bride price (p. 151). Due to these debasing aspects of local cultures by which women are treated as commodities, Emecheta states that "women are the money" that are "being sold" and "[they] have to abolish that before [they] start being independent" (p. 151).

Polygamy is another cultural practice prevalent in most parts of Nigeria. In most Nigerian communities, polygamy is regarded as a legal marital institution wherein a man marries more than one wife and provides for them equally. However, in The Stillborn, some male characters deviate from its legal obligation and regard this status as a means to an end. For instance, Garba, who is the only person having first-hand experience of city life, favours polygamy by stating that in the city a man "can acquire many wives without slaving for them"; rather, they all slave for him (The Stillborn, 1984, p. 45). He furthers his account by adding that "in the city you do not have to live together in the same house" and that he has a friend who "keeps four women in four different areas of the city" but "none of them knows the others exists and they all slave for him!" (p. 45). Ignoring the presence of the women, Garba boasts about the opportunities that the city offers to men. However, his views as to both tradition and modernisation are contradictory. On the one hand, he favours polygamy judging as a typical male representative brought up by the values of a traditional patriarchal society. On the other hand, by stating that in the city, a man "can acquire many wives without slaving for them", he deviates from the liability of the traditional polygamous marriage (p. 45). Garba attempts to adjust polygamy so as it suits his needs, which, in the Derridean sense, may be interpreted as a supplement to the existing system. In terms of supplementarity, Garba's attitude may be described as a lopsided perception of both traditional and modern values, which he prefers to call the virtues of city life or, as he puts it, "civilisation". It is impossible to designate Garba's assumed values as either traditional or modern since they exclusively serve his own interests. In terms of deconstruction, this logocentric approach also reveals the effect of patriarchy in the Nigerian culture by which the masculine is favoured in the construction of meaning. Hence, by legitimising binaries, the power of logocentrism enables the male perspective to perpetuate gender inequality in society.

Florence Stratton (1994) argues that before the advent of women's writing in African literature, polygamy was never dealt with by male authors and "[the] exclusion of patriarchy as a determinate historical, social, and political condition has a number of interrelated consequences for current theories of African literature" (p. 171). In The Stillborn, this attitude is observed in the discussion of polygamy through the display of heterogeneous ideas expressed by both male and female characters. For instance, Awa, Habu and Dan Fiama react to the 'city wisdom' keenly propagated by Garba producing various justifications. Awa condemns Garba's account of married life in the city by calling it 
prostitution rather than marriage (The Stillborn, 1984, p. 45). Dan Fiama, on the other hand, does not approve of Garba's approach to polygamy stating that in the traditional polygamous marriage "each woman looks after herself and her children, while the man keeps a common barn" (p. 45). Habu expresses his indignation by stating that it is impossible for a man to love all of his wives at the same time (p. 45). Although the young members of the rural society cannot come against their tradition, they may use it as a tool for disguise just like Dan Fiama, who only appears to be a traditional family man. On the one hand, he does not consider himself "a suitable candidate for polygamy" and believes that polygamous marriage "kills manhood"; on the other hand, this perception does not prevent him "from taking his pleasures elsewhere" (p. 46). Awa is also disapproving of polygamous marriage. However, she does not endorse this practice simply because children of different mothers' dislike and distrust each other and co-wives are constantly vying jealously for the husband's favour, which creates a tense atmosphere at home (p. 46). In this sense, her views are similar to Garba's logocentric attitude since neither are concerned about how polygamous marriage affects a woman and her feelings. Another female character, Faku produces another perspective on polygamy. As a female, she is expected to disapprove of the practice of polygamy since it is degrading to women. On the contrary, she does not see anything wrong with that, particularly concerning Garba's views. She resorts to polygamy as salvation to improve her living conditions and an ultimate solution to her predicament.

She would like to be Garba's only wife. What woman wouldn't? But if the man could afford to feed a dozen other wives, who was she to object? For her, polygamy wasn't the point at all. The point was that once she married, living alone with her mother was over. They would no longer have to work their fingers sore to feed themselves or mend the leaking roof, because someone else would be responsible. She did not seem to have taken in Garba's gibe about women slaving for men. (The Stillborn, 1984, p. 46)

Obviously, the young generation is torn between advantages and disadvantages of their culture. This impasse or contradiction suggested by the text on the discussion of polygamous marriage is associated with Derrida's aporia, by which "the context neither produces nor guarantees impassable borders" (Aporias, 1993, p. 9). Another issue in The Stillborn that is worth considering is male child preference. Li's father, Baba, favours his son over his daughters by ignoring his mistakes and directing all the criticisms, rebukes and punishments at his daughters. This unfair treatment stems from the same patriarchal norms enabling men to be held in high esteem as compared to women in the Nigerian society. According to Raji (2016), "ideas about manhood are deeply embedded" in Nigeria and that "from an early age, male children may be socialized into gender roles aimed at keeping men in power and control" (p. 59). Hence, "the root causes of male child preference are "the underlying patriarchal attitudes and behaviour, as well as discriminatory gender norms and structures" (p. 59). Similarly, in her internationally acclaimed essay "Feminism with a Small ' $\mathrm{f}$ '!", Emecheta states that in many parts of Africa "only one's enemies will go out to pray for a pregnant woman to have a girl-child" (1988, p. 179). Since most people prefer a man-child, the prayers go as follows: "You will be safely delivered of a bouncing baby boy, a real man-child that we can and make jolly with whisky and beer" (p. 179). Moreover, the pregnant woman does not protest at these prayers because she also wants to have a man-child, who "will not be married away, but will stay in the family home and look after his mother when she becomes weak and old" (p. 179). Based on her first-hand experience, Emecheta argues that in most African societies the birth of a son enhances a woman's authority in the family (p. 179). On the other hand, "a girl-child is conditioned into thinking that being the girl, she must do all the housework, she must help her mother to cook, clean, fetch water and look after her younger brothers and sisters" (p. 179). If she complains, she is sharply reminded by her mother that she is a girl who is going to be a woman (p. 179).

In The Stillborn, the predicament of the Nigerian female subaltern is made worse by such issues as fertility and impotence. It is pointed out that a woman is even more desperate in her society particularly if she is left on her own. In this regard, the inclusion of the minor character - Hajiya, the owner of the city house where Li settles with her husband is not coincidental. In doing so, the author accentuates the importance of potency and fertility in the Nigerian patriarchal society. Hajiya marries at a very young age but since she cannot procreate, her husband remarries several women with whom he has many children. Hajiya experiences a deep emotional pain with every birth in the family and 
polygamy only adds to her state of childlessness. Hajiya finds herself in a situation when she is held responsible for infertility. Bereft of the role of motherhood and pushed to the background, she feels marginalised and estranged at her husband's home. She cannot find her place in the family thereby exercising her position from the periphery. As a result, she is reduced to a permanent state of subalternity. In this sense, Hajiya is the archetype of all the women who are burdened with fertility rites enforced by their patriarchal communities. She expresses her womanly feelings when she confesses to Li that "it is painful and hard when you have no man or child to hug" (The Stillborn, 1984, p. 73).

It is noteworthy that the novel also reveals how Nigerian men treat the issue of infertility. As a reaction to the male critical discourse that valorises and idealizes womanhood and motherhood within the conventional framework, Alkali portrays a male character, Manu, who is a "miserly bachelor" and "notorious woman-hater" (p. 53). He knows that he is unable to copulate but does not dare to reveal his vulnerable state, which explains his misogynistic attitude. Manu's impotence challenges the logocentric attitude of infertility traditionally ascribing childlessness to women. His impotence stands for male powerlessness and incompetence. His situation is epitomised by a wise old saying that "the chicken is better left in its feathers" since "that way you never know how thin it is" (p. 54). The juxtaposition of Hajiya's plight and Manu's ironic situation demonstrates that the position of the Nigerian subaltern is predetermined by the strict norms of the male dominated society. In this regard, Ngcobo (1988) explains that fertility is important to African families since "[a] man sees it as a sacred duty towards his whole lineage" (p. 142). Therefore, it is a taboo and a shame if a man fails to immortalise the ancestors (p. 142). As a result, childlessness is associated with women, and otherwise is unthinkable (p. 142).

The subaltern position of the female characters Li, Awa and Faku gains prominence in their conjugal relations with their partners Habu, Dan Fiama and Garba, respectively. Their aspirations are clearly manifested in the initial dreams. Faku is determined to marry Garba and settle in the city. Thus, overwhelmed by the city fever, she cannot wait to leave the village. Also, the city is Faku's escape from the pressure of the suffocating conventions of her community. She even "expressed great pity for the two sisters whom she believed would never be privileged to see the city lights" (The Stillborn, 1984, p. 56). Faku is not disturbed by Garba's shadowy and insecure background. Moreover, she does not mind marrying a man who has another family in the city. The mind-set imposed by the tradition of her community does not allow her to question her position and her ignorance only adds to this condition. On the other hand, Awa is not concerned with the city, which is aptly stated in her response to Faku that "[they] need not go to the city. The city will come to [them]. The government will soon take over all schools and hospitals. That means rapid development" (p. 56). However, the dreams of these women are shattered by their repressive and alcoholic husbands.

$\mathrm{Li}$, on her part, still dreams about modern life in the city. The passage describing her anticipation after her husband's departure constitutes the breaking point of the protagonist. The suspense in her life discourages her from the goals that she has endeavoured to achieve. "Her mind went back over the last four years when her life and her hopes had been different from what they were now" (p. 56). All the dreams about "the qualified doctor, the Grade I teacher, the big European house full of servants" remained as dreams, though "the future was in their hands" (p. 57). The manner of anticipation is emphasised by the recurrent use of the signifier 'still' that suggests various connotations: "Four years later, $\mathrm{Li}$, a young woman of nineteen, sat still on a mat, her legs crossed in a meditative position... Now four years later, here she was, still in the village, still waiting for Habu... She was still waiting..." (pp. 56-57). In the Derridean sense, the difference and deferral of the signifier 'still' is disseminated in the passage indicating various signifieds producing différance, which explains Li's state of inaction towards the circumstances that delay materialisation of her dreams. However, due to her ambitious and rebellious personality, she eventually puts an end to her vain anticipation by asking: "How long can a woman wait for a man?" (p. 63). This rhetorical utterance is an epiphany epitomising Li's rebellion against tradition that relegates the woman to the subaltern position.

Li's mother is another strong female character, whose prominence comes to the fore with her father's death. Until that time, her existence in the house did not matter to anybody, including $\mathrm{Li}$. Li is shocked 
to discover that when being away from home, the whole family lived on the proceeds of her mother's farm. Awa admits that "[she] wouldn't have known how to cope without Mama", who "would go to the farm at cockcrow and won't come back until the chickens have gone to roost" (p. 87). Li's mother may initially seem a traditional subaltern silently suffering Baba's derision; however, after her husband's death, she proves to be a strong and self-determined woman. She virtually becomes the 'man of the house' proving as capable as men in undertaking particular household and economic responsibilities. Nnaemeka (1997) argues that

While some feminist analyses of the African novel conflate silence (the noun) and silence (the verb), the novels themselves make a distinction between "to be silenced" and "to be silent" (the former as imposition and the latter as choice). One exercises agency when one chooses not to speak; the refusal to speak is also an act of resistance that signals the unwillingness to participate. (p. 4)

This view suggests that Li's mother's silence observed throughout the novel does not mean a lack of agency since "victims are also agents who can change their lives and affect other lives in radical ways" (Nnaemeka, 1997, p. 3). Moreover, the fact that she is never named in the novel makes it possible to regard her as an archetype characterising the concept of African feminism. This theory endorses motherhood and defines it as the "source of supreme power" (Newell, 2006, p. 153). Li's mother becomes an inspirational character in her future accomplishments, which echoes Baba's adage that "the lion cub takes after its mother" (The Stillborn, 1984, p. 13). She begins to appreciate her mother's difficulties when she goes through unpleasant trials of city life. Hajiya's polygamous and childless life instils patience in Li. She learns a valuable lesson that patience "does not sour no matter how long you keep it" and "a patient person could cook a rock and drink the soup" (p. 73). Although Li's initial assumption of marriage as a way to materialise her aspirations fails her, she eventually finds strength to recover from these stillborn dreams by completing her education and becoming a successful teacher.

Ultimately, the death of Li's grandfather, which signifies the end of old values, and her brother's avoidance of family responsibilities entitle her to the position of "the man of the house" (p. 101). Li's newly acquired role is associated with patriarchy and male power, which shows that "woman can be relied upon where the men have failed" (Okereke, 1996, p. 114). This is clearly manifested by the end of the novel when $\mathrm{Li}$ visits her village having become an accomplished person and owner of a huge modern building in the city. She also realises that "the bond that had tied her to the father of her child was not ruptured" (The Stillborn, 1984, p. 105). Empowered with her self-made position and hailed as "the man of the house", Li decides to rebuild the broken relationship with her husband (p. 101). Moreover, she returns to her husband at the time when a car accident leaves him crippled and helpless. Ironically, Li's sister, who believes that "to break up a home is like breaking a child", tries to dissuade her from reuniting with her husband (p. 88). She explains that Li may occupy a superior position in the family if she 'holds the crutches', thereby leading the way. On the other hand, Li may as well remain a traditional subaltern by 'walking behind' her husband (p. 105). Of the two options, she chooses neither by trying to find middle ground between her private and public realm. Supporting her husband both physically and psychologically, $\mathrm{Li}$ assures him that "this is no time to crawl. It is time to learn to walk again," and that "side by side we will learn to walk" (p. 105). Having secured her private and public space through education and a new status as 'the man of the house', Li returns to the city for further improvement.

The significance of Li's name is another remarkable aspect in the book. Li informs that her name is short for Libira, which means 'needle' in the Hausa language (p. 5). She adds that this name identifies her as somebody who "can never stay in one place for long" (p. 6), which is aptly described in the epilogue when $\mathrm{Li}$, having accomplished her goals, is eager to continue her struggle, "for that [is] the only way life [can] be meaningful" (p. 102). It is also noteworthy that the book was written in English, which makes it possible to examine the signification of the name in terms of deconstruction. Libira, as a signifier, evokes two signifieds: libra and liberty. In The Stillborn, libra stands for equality and harmony balancing the relationship between men and women, whereas liberty represents Li's independent spirit and free will of self-realisation. In the play of signification, these signifieds 
complement each other and produce différance which conveys a womanist message encapsulated in Li's self-determined and cooperative stance to walk side by side with her husband.

To conclude, The Stillborn challenges the norms of the gender binary calling into question maledominated traditions by which women's role is limited to domestic sphere and childbearing. The main female character Li believes that marriage is an institution in which neither side is superior to the other; on the contrary, one complements the other forming a harmonious alliance. Hence, according to Derrida's deconstruction, both sides of the gender binary come under erasure producing a play of differences. In addition to this, Li's conciliatory stance is consistent with African feminism since it also embraces solidarity between men and women. Another aspect corresponding with this discourse is Li's attempt to improve her condition and go beyond the boundaries of patriarchal society. She aspires to be regarded as a woman and a human rather than a subaltern subject. In this respect, she also conveys a womanist message consisting in self-determination and perseverance of the Nigerian woman. Empowered with her self-made status, she creates a vision of a better life based on equal opportunities in society. Moreover, Li's articulation of female agency is demonstrated in her journey to the city in search of education which also becomes a synonym for the female subaltern's selfrealisation. Her exposure to urban reality contributes to her social awakening and coupled with education offers her the opportunity to extricate herself from the oppressive bonds of tradition. $\mathrm{Li}$ defies these repressive aspects of her culture and does not accept subalternity as the status quo. She gives voice to all the female subalterns who are obliged to remain silent to the circumstances making them inferior in the male-dominated world.

Bilgilendirme / Acknowledgement:

1- Bu makale, yazarın 'Zaynab Alkali'nin The Stillborn, Buchi Emecheta'nın Kehinde ve Sefi Atta'nın Everything Good Will Come Eserlerindeki Nijeryalı Alt Sınıf Kadınlarının Durumunun Yapıbozucu Açıdan Okunması” adlı doktora tezinin bir bölümünün gözden geçirilmiş halidir.

2- Makalemde etik kurulu izni ve/veya yasal/özel izin alınmasını gerektiren bir durum yoktur.

3- Bu makalede araştırma ve yayın etiğine uyulmuştur.

\section{REFERENCES}

Alkali, Z. (1984). The Stillborn. Harlow: Longman Group.

Bayu, E. K. (2019). A comparative analysis on the perspectives of African feminism vs. Western feminism: Philosophical debate with their criticism and its implication for women's rights in Ethiopian context. International Journal of Sociology and Anthropology, 11(4), 54-58.

Busby, M. (1996). Foreword. In M. Umeh (Ed.) Emerging perspectives on Buchi Emecheta. (pp. xiiixix). New Jersey: Africa World Press.

Derrida, J. (1997). Of Grammatology. (G. Spivak, Trans.). Baltimore: Johns Hopkins University Press.

Derrida, J. (1993). Aporias (T. Dutoit, Trans.). Stanford: Stanford University Press.

Emecheta, B. (1988). Feminism with a small ' $\mathrm{f}$ '! In K. H. Peterson (Ed.) Criticism and ideology: Second African writers' conference (p. 179). Uppsala: Scandinavian Institute of African Studies.

Falola, T., \& Matthew M. Heaton. (2008). A history of Nigeria. Cambridge: Cambridge University Press.

Harmon, D. E. (2001). Exploration of Africa: The emerging nations: Nigeria. Philadelphia:Chelsea Press.

James, A. (1990). In their own voices: African women writers talk. London: Heinemann.

Kolawole, M. E. M. (1997). Womanism and African consciousness. Trenton, NJ: Africa World Press.

Newell, S. (2006). West African literatures: Ways of reading. Oxford: Oxford University Press. 
Ngcobo, L. (1988). African motherhood - myth and reality. In K. H. Peterson (Ed.) Criticism and ideology: Second African writers' conference (pp. 142-151). Uppsala: Scandinavian Institute of African Studies.

Nnaemeka, O. (1997). Introduction: Imag(in)ing knowledge, power, and subversion in the margins. In The politics of (m)othering: Womanhood, identity and resistance in African literature. (pp. 3-4). London: Routledge.

Nnoromele, S. C. (2002). Representing the African woman: Subjectivity and self. The joys of motherhood. Critique: Studies in contemporary fiction, 43(2), 178-190.

Okereke, G. E. (1996). Woman's quest for autonomy in Zaynab Alkali's The Stillborn. Ufahamu: A Journal of African Studies, 242(3), 97-120.

Phillips, D. A. (2004). Modern world nations: Nigeria. Philadelphia: Chelsea Press.

Pittin, R. I. (2002). Education - issues of gender, class and ideology. In Women and work in Northern Nigeria: Transcending boundaries (pp. 340-351). New York: Palgrave MacMillan.

Raji, A., et al. (2016). Socio-cultural factors and male-child preference among couples in Ilorin - west local government area of Kwara-State, Nigeria. Ethiopian Journal of Social Sciences and Language Studies, 3(1), 57-72.

Spivak, Gayatri Chakravorti. (1987). Can the subaltern speak? In C. Nelson \& L. Grossberg (Eds.) Marxism and the interpretation of culture (pp.294-308). Chicago: University of Illinois Press.

Stratton, Florence. (1994). Contemporary African literature and the politics of gender. London: Routledge.

Ugbabe, Kanchana (1998). Zaynab Alkali. Journal of Language and Literature, 4, 13-18.

Whitsitt, Novian. (2012). Zaynab Alkali. In E. K. Akyeampong \& H. L. Gates, Jr. (Eds.) Dictionary of African biography 1. Oxford: Oxford University Press. 